\title{
Current Pattern of Product Specific Smokeless Tobacco Use in Bangladesh
}

\section{Munjila Begum and Papia Sultana*}

Department of Statistics, University of Rajshahi, Bangladesh

\begin{abstract}
Background: Tobacco use is one of the foremost causes of preventable morbidity and mortality. The objective of the study was to identify the pattern of smokeless tobacco use and to estimate the prevalence and to identify Socio-
\end{abstract} demographic correlates of smokeless tobacco consumption.

Data and methods: We used the data from the 2010 Global Adult Tobacco Survey (GATS) in Bangladesh. The data were representative for men and women aged 15 years and above. The survey was based on a three-stage stratified cluster sample of household. Information of a total of 9629 adults, aged 15 years and over, was analyzed by stratified them into urban (4857) and rural (4772) groups. Stata Version 11.0 and Excel were used to analyze the dataset. Predictors of prevalence for smokeless tobacco use were analyzed using selected socioeconomic and demographic characteristics that include residence, age, gender, education, occupation and wealth index. Associations between smokeless tobacco consumption and the explanatory variables were estimated using simple and multiple logistic regression model.

Results: Current smokeless tobacco users daily were significantly higher $(p=0.001)$ in urban females $(21.92 \%)$ in comparison to urban males $(18.13 \%)$ and also significantly higher $(p<0.001)$ in rural females $(30.60 \%)$ in comparison to rural males $(25.92 \%)$. In the multivariate analysis the adjusted $O R$ were significantly higher in rural area $(O R=1.15$, $95 \% \mathrm{Cl}=1.02-1.29)$ in comparison to urban area. Similarly adjusted OR were significantly higher in females (OR=1.68, $95 \% \mathrm{Cl}=1.38-2.30)$ in comparison to males. The adjusted OR increased with age from $3.09(95 \% \mathrm{Cl}=2.45-3.93)$ in the age group 25-34 to $12.70(95 \% \mathrm{Cl}=10.02-16.11)$ among individuals with 46 years and above age group, in comparison to individuals in the age group less than or equal to 24 years. Education and smokeless tobacco use showed significant inverse relationship with significantly elevated OR in the low education group (no formal schooling, OR=4.28, 95\% $\mathrm{Cl}=2.48-7.38)$, less than primary school completed $(\mathrm{OR}=3.28,95 \% \mathrm{Cl}=1.89-5.68)$ and primary school completed $(\mathrm{OR}=3.61,95 \% \mathrm{Cl}=2.08-6.29)$ in comparison to high education group (post graduate degree).

Conclusion: The prevalence of current smokeless tobacco consumption is high among rural women and among all smokeless tobacco products, the prevalence of the use of betel quid with tobacco was the highest in Bangladesh. Awareness should be given priority to decrease the growing smokeless tobacco consumption. Also tobacco control campaigns should target rural poor older women and monitor all forms of smokeless tobacco products used by the population.

Keywords: Global adult tobacco survey; Smokeless tobacco; Sociodemographic determinants; Pattern; Logistic regression

\section{Introduction}

People are taking tobacco in numerous forms or patterns for various purposes and the prevalence of tobacco consumption is nurturing alarmingly in most of the low and middle income countries. About 6 million people die from tobacco-related causes every year globally. Based on present pattern of tobacco use it is estimated that there could be one billion premature deaths globally during the $21^{\text {st }}$ century. Immediate dealings are required to decrease the tobacco consumption which can decrease the health hazard of many people. Tobacco is derived from the plant Nicotiana Tabacum. There are different types of tobacco e.g. smokeless tobacco and smoked tobacco. Smokeless tobacco includes tobacco with pan masala, tobacco with pan and betel quid, and tobacco with lime [1]. Smokeless tobacco consumption (STC) causes oral, head and neck cancer, diabetes, hypercholesterolemia, myocardial infarction and adverse effects on pregnancy [2]. Smokeless tobacco use is very prevalent worldwide. For example, it is estimated that there are some 600 million users of areca nut/tobacco mixtures (betel quid or paan), primarily in the Indian subcontinent and South East Asia. Amongst South Asians tobacco is most commonly chewed by adding it to paan (the terminology can be confusing because it is not used consistently. For example, paan can be used to refer to the mixture including tobacco.). Paan consists of three basic ingredients: the betel leaf, betel nut and lime paste. A range of ingredients are added to these, one of which can be tobacco. Several large population-based epidemiological studies in India show almost all regular chewers of betel quid chew it with tobacco. In the US it is estimated that there are some 5 million adult and 750,000 adolescent smokeless tobacco users (mainly chewing tobacco and moist snuff). Manufactured smokeless tobacco products prevail in the USA and Sweden whereas in South Asia traditional tobacco products prevail which are more diverse in manufacture and complex in consumption, making identification of any impact more difficult. The CDC (Center for Disease Control) is also producing a series of fact sheets about different types of smokeless tobacco use around the world (www.cdc.gov). The 1999 annual Health Survey for England focused on black and minority ethnic groups and reported that some form of oral tobacco was used by $19 \%$ of Bangladeshi men, $6 \%$ of Indian men, $2 \%$ of Pakistani men, $26 \%$ of Bangladeshi women, $2 \%$ of Indian women and $2 \%$ of Pakistani women [3]. Also Bangladesh has a long history of tobacco use and a variety of ways in which tobacco is smoked and smokeless tobacco is

*Corresponding author: Sultana P, Department of Statistics, University of Rajshahi, Bangladesh, Tel: +880 721-750244; E-mail: papia.stat@ymail.com

Received July 19, 2017; Accepted August 12, 2017; Published August 22, 2017

Citation: Begum M, Sultana P (2017) Current Pattern of Product Specific Smokeless Tobacco Use in Bangladesh. J Biom Biostat 8: 362. doi: 10.4172/21556180.1000362

Copyright: @ 2017 Begum M, et al. This is an open-access article distributed under the terms of the Creative Commons Attribution License, which permits unrestricted use, distribution, and reproduction in any medium, provided the original author and source are credited. 
used. The limited data that are available on smokeless tobacco (SLT) use in Bangladesh indicate an increasing trend in both male and female adults (aged 15 and above). SLT use has increased from 19.7\% (14.8\% male and 24.4\% female) in 2004 Zaman MM et al. [4] to $27.2 \%$ (26.4\% male and 27.9\% female) in 2009 [5]. By converting these percentages in numbers, it can be estimated that the number of SLT users increased by 9 million in five years (from 17.3 million to 25.9 million).

Despite the health hazards of SLT consumption, there have been only a few studies conducted on SLT consumption in Bangladesh. However, very little is known about the general pattern of product specific smokeless tobacco consumption and about the population groups who are more susceptible to to smokeless tobacco consumption. This paper aims to estimating current pattern and prevalence of smokeless tobacco consumptions in Bangladesh, especially emphasizing identification of socio-demographic groups who are more susceptible to to tobacco consumption.

\section{Data and Methodology}

In this paper secondary data collected by the Global Adult Tobacco Survey (GATS), 2010 (GATS report, 2010) has been used. The survey was conducted in 14 countries including Bangladesh, Brazil, China, Egypt, India, Mexico, Philippines, Poland, Russia, Thailand, Turkey, Ukraine, Uruguay and Vietnam from 2008 to 2010. GATS used a global standardized methodology. It included information on the respondents' background characteristics, tobacco use (smoking and smokeless), cessation, second-hand smoke, economics, media, and knowledge, attitudes and perceptions of tobacco use. In Bangladesh, GATS was conducted in 2009 as a household survey of persons 15 years of age or older by the National Institute of Preventive and Social Medicine in collaboration with the Bangladesh Bureau of Statistics (BBS) and National Institute of Population Research and Training (NIPRT). A multi-stage (three-stage), geographically clustered sample design was used to produce nationally representative data. At the first stage 400 Primary Sampling Units (PSU) s (Mauza in rural and Mohalla in urban areas) were selected with probability proportional to size (PPS), followed by a random selection of one Secondary Sampling Unit (SSU) per selected PSU. At the third stage households were selected systematically within the listed households from a selected SSU. One individual was randomly chosen from each selected household to participate in the survey. Survey information was collected using handheld devices. The household response rate was $97.7 \%$, the individual response rate was $95.8 \%$ and the overall response rate was $93.6 \%$. There were a total of 9629 completed interviews (male $=4468$ and female $=5161$ ) (Global Adult Collaborative Group). Details about the survey methods, questionnaire, and definitions of various terminologies can be found in GATS's website [5-7].

The wealth index used for the analysis was constructed by the GATS Collaborator Team using one of the multivariate approach (principal component analysis). Asset information covered household ownership of a number of items, such as electricity, flush toilet, fixed telephone, cell telephone, television, radio, refrigerator, car, moped/scooter/ motorcycle, washing machine, bicycle, sewing machine, almirah/ wardrobe, table, bed or cot, chair or bench, watch or clock, as well as the type of main material used for the roof of the main house (cement, tin and katcha such as bamboo/thatched/straw). Each asset was assigned a weight (factor score) generated through principal components analysis, and the resulting asset scores were standardized in relation to a normal distribution with a mean of zero and standard deviation of one. Each household was then assigned a score for each asset, and the scores were summed for each household; individuals were ranked according to the total score of the household in which they resided. The sample was then divided into quintiles from one to five. One stands for lowest and five stands for highest. A single asset index was developed for the whole sample; indices were not prepared clustering to residential area and gender [7]. The term current smokeless tobacco users includes 'daily' and/or 'occasional (less than daily)' tobacco users in this paper.

\section{Statistical Methods}

Both basic and advanced statistical methodologies have been used to analyze the data. Descriptive analysis has been performed to know the characteristics of the study subjects. For that frequency with percentage has been reported as the variables are categorical. A comparison of socio-demographic and economic characteristics of study subjects to current smokeless tobacco user has been performed. To compare variables chi-square test (Pearson Chi-square or Likelihood Ratio Chisquare whichever applicable) has been used, and prevalence with $95 \%$ confidence interval has been reported for individual variable. These tests have been performed at $5 \%$ level of significance. To analyze the socio-demographic and economic predictors to current smokeless tobacco use binary logistic regression. Age adjusted and unadjusted prevalence has been reported, too. Statistical software StataSE version 11 (StataCorp, USA) has been used to carry out statistical analyses. Missing data on "age" and "occupation" has been adjusted using related information [7]. For example, missing data on age has been adjusted using year of birth; missing data on occupation has been adjusted using information on educational status and age, those were for students and elderly persons, only. However, missing data on educational level $(0.66 \%)$ cannot be adjusted as no other supportive variable is available. For advanced analysis missing data has been avoided and thus sample size 9565 has been used in the advanced analysis. However, it has been found that distribution of level of education and work status are much skewed. Therefore, level of education and work status are rearranged at the time of advanced analysis.

\section{Results}

It has been observed that equivalent numbers of subjects were surveyed from rural and urban area (50.44\% from urban and $49.56 \%$ from rural) (Table 1). Among the survey subjects, females are a bit more than males (46.40\% male and $53.60 \%$ female). Most of the subjects are of no formal schooling (35.48\%) and most are of homemaker/ housework $(41.85 \%)$. It has been observed that prevalence of male smokeless tobacco (daily) user in Bangladesh is 21.93 and prevalence of female smokeless tobacco (daily) user is 26.27 (Table 2). Table 3 presents pattern of smokeless tobacco product used among the users in Bangladesh stratified by area of residence and gender. It has been found that most used smokeless tobacco product is betel quid with zarda (79.18\% male and $58.04 \%$ female).

Prevalence of smokeless tobacco use is relatively higher in rural area $(58.13 \%)$ than in urban area $(41.87 \%)$. Older people (larger than 45 years old) use smokeless tobacco product most (44.73\%) (Table 4). Most of the smokeless tobacco users have no formal schooling (57.08\%), are homemaker/houseworker $(45.68 \%)$, and are of poorest wealth index $(27.31 \%)$. Wealth index and level of education are gradually and significantly ( $p$-value $<0.001)$ decreasing the use. It is also found that age is gradually and significantly ( $p$-value $<0.001$ ) increasing the use. Age adjusted and unadjusted prevalence of smokeless tobacco use with $95 \%$ confidence interval has been reported, too (Table 5). It has been found that age adjusted and unadjusted prevalence of smokeless tobacco use differs only for work status which is expected. 


\begin{tabular}{|c|c|}
\hline Demographic Characteristics & Sample size $=9629$ \\
\hline \multicolumn{2}{|l|}{ Residence $(\%)$} \\
\hline Urban & $4,857(50.44)$ \\
\hline Rural & $4,772(49.56)$ \\
\hline \multicolumn{2}{|l|}{ Gender (\%) } \\
\hline Male & $4,468(46.40)$ \\
\hline Female & $5,161(53.60)$ \\
\hline \multicolumn{2}{|l|}{ Age $(y)(\%)$} \\
\hline$\leq 24$ & $2,073(21.53)$ \\
\hline $25-34$ & $2,665(27.68)$ \\
\hline $35-45$ & $2,537(26.35)$ \\
\hline$\geq 46$ & $2,354(24.45)$ \\
\hline \multicolumn{2}{|l|}{ Level of Education (\%) } \\
\hline No formal schooling & $3,416(35.48)$ \\
\hline Less than primary school completed & $1,487(15.44)$ \\
\hline Primary school completed & $1,115(11.58)$ \\
\hline Less than secondary school completed & $1,937(20.12)$ \\
\hline Secondary school completed & $663(6.89)$ \\
\hline High school completed & $463(4.81)$ \\
\hline College/University completed & $273(2.84)$ \\
\hline Post graduate degree completed & $211(2.19)$ \\
\hline \multicolumn{2}{|l|}{ Work Status (\%) } \\
\hline Government employee & $221(2.30)$ \\
\hline Non-Government employee & $740(7.69)$ \\
\hline Business-small & $865(8.98)$ \\
\hline Business-large & $128(1.33)$ \\
\hline Farming (land owner and farmer) & $826(8.58)$ \\
\hline Agricultural worker & $374(3.88)$ \\
\hline Industrial worker & $214(2.22)$ \\
\hline Daily laborer & $631(6.55)$ \\
\hline Other self-employed & $308(3.30)$ \\
\hline Student & $461(4.79)$ \\
\hline homemaker/housework & $4030(41.85)$ \\
\hline Retired & $114(1.18)$ \\
\hline unemployed, able to work & $151(1.57)$ \\
\hline unemployed, unable to work & $162(1.68)$ \\
\hline Other & $394(4.09)$ \\
\hline \multicolumn{2}{|l|}{ Wealth Index } \\
\hline Richest & $1,923(19.97)$ \\
\hline Rich & $2,040(21.19)$ \\
\hline Middle & $1,732(17.99)$ \\
\hline Poor & $2,068(21.48)$ \\
\hline Poorest & $1,866(19.38)$ \\
\hline
\end{tabular}

Note: Wealth index was calculated using principal component analysis. Asset information covered household ownership of a number of items, such as electricity, flush toilet, fixed telephone, cell telephone, television, radio, refrigerator, car, moped/scooter/motorcycle, washing machine, bicycle, sewing machine, almirah/ wardrobe, table, bed or cot, chair or bench, watch or clock, as well as the type of main material used for the roof of the main house (cement, tin and katcha such as bamboo/thatched/straw).

Table 1: Characteristics of Study subjects (GATS, 2010).
Adjusted and Unadjusted relationships of sociodemographic and economic variables have been analyzed to find the predictors of current smokeless tobacco use (Table 6) using binary logistic regression. It has been found that respondents of rural area are significantly and more likely to use smokeless tobacco (unadjusted $\mathrm{OR}=1.58,95 \% \mathrm{CI}=1.44$, 1.73; adjusted $\mathrm{OR}=1.13,95 \% \mathrm{CI}=1.00,1.26$ ). Females are significantly and more likely to use smokeless tobacco currently (unadjusted $\mathrm{OR}=1.27,95 \% \mathrm{CI}=1.15,1.39$; adjusted $\mathrm{OR}=1.70,95 \% \mathrm{CI}=1.41,2.05$ ). Older group (greater than or equal 45 years) respondents are 16 times more likely to use smokeless tobacco than youngest group (less than or equal to 24 years) (unadjusted $\mathrm{OR}=16.44,95 \% \mathrm{CI}=13.19,20.49$ ). For adjusted model, the older group is found to be about 15 times more likely to use than the youngest group $(\mathrm{OR}=14.72,95 \% \mathrm{CI}=11.61$, 18.61). Respondents of age groups 25-34 years are 3 times more likely (unadjusted $\mathrm{OR}=3.86,95 \% \mathrm{CI}=3.07,4.86$; adjusted $\mathrm{OR}=3.61,95 \%$ $\mathrm{CI}=2.85,4.57)$ and respondents of age group $35-44$ years are 8 times more likely (unadjusted $\mathrm{OR}=9.04,95 \% \mathrm{CI}=7.24,11.28$ and adjusted $\mathrm{OR}=8.48,95 \% \mathrm{CI}=6.72,10.71$ ) to use smokeless tobacco than youngest age group. Respondents with no formal schooling are most likely to use smokeless tobacco than respondents of all educational level for both adjusted and unadjusted model. Work status does not seem to have any significant pattern of influence to smokeless tobacco use for adjusted model, although in unadjusted model respondents of some work status are found to be more likely to use smokeless tobacco than government and non-government employee. Respondents of poorest group are most likely to use smokeless tobacco than respondents of richest group.

\section{Discussion}

This study is based on a country representative cross-sectional study of Bangladesh. Prevalence of smokeless tobacco use of this study reveals that one in every five men and one in every four women currently use smokeless tobacco daily/occationally in Bangladesh. The use is more prevalent in rural area and among older subjects. Subjects with no formal schooling and of lowest wealth index are most likely to use smokeless tobacco.

The observation that smokeless tobacco use increases with age is consistent with previous reports $[4,8]$. Also rural peoples in neighboring country like India Mishra et al. [9], Roobon et al. [10] used chewing substances more as is found in this study for Bangladesh. Our finding shows that female use smokeless tobacco more which is identical to other study [11]. Similar pattern had been found for Bangladeshi community in UK [12].

Compared to developed countries, the smokeless tobacco issue in the South East Asian Region (SEAR) is much more complex. This is because of several reasons such as wide range of products with varying components, unregulated and unorganized market forces, and production and sale in informal settings [13].

Our study provides information about prevalence and patterns of smokeless tobacco use among men and women in Bangladesh not

\begin{tabular}{|c|c|c|c|c|c|c|c|c|c|}
\hline & \multicolumn{3}{|c|}{ Urban $(n=4857)$} & \multicolumn{3}{|c|}{ Rural (n=4772) } & \multicolumn{3}{|c|}{ Total $(n=9629)$} \\
\hline & Male & Female & P-value & Male & Female & $\mathrm{P}$-value & Male & Female & $P$-value \\
\hline Daily & 18.13 & 21.92 & 0.001 & 25.92 & 30.60 & $<0.001$ & 21.93 & 26.27 & $<0.001$ \\
\hline Less than daily & 5.95 & 1.98 & $<0.001$ & 6.18 & 1.24 & $<0.001$ & 6.07 & 1.61 & $<0.001$ \\
\hline Not at all & 75.92 & 76.1 & 0.884 & 67.90 & 68.16 & 0.849 & 72.00 & 72.12 & 0.899 \\
\hline
\end{tabular}

Note: Less than daily indicates occasionally. P-values are obtained from Z-test for proportion. 
Citation: Begum M, Sultana P (2017) Current Pattern of Product Specific Smokeless Tobacco Use in Bangladesh. J Biom Biostat 8: 362 . doi: $10.4172 / 2155-6180.1000362$

Page 4 of 6

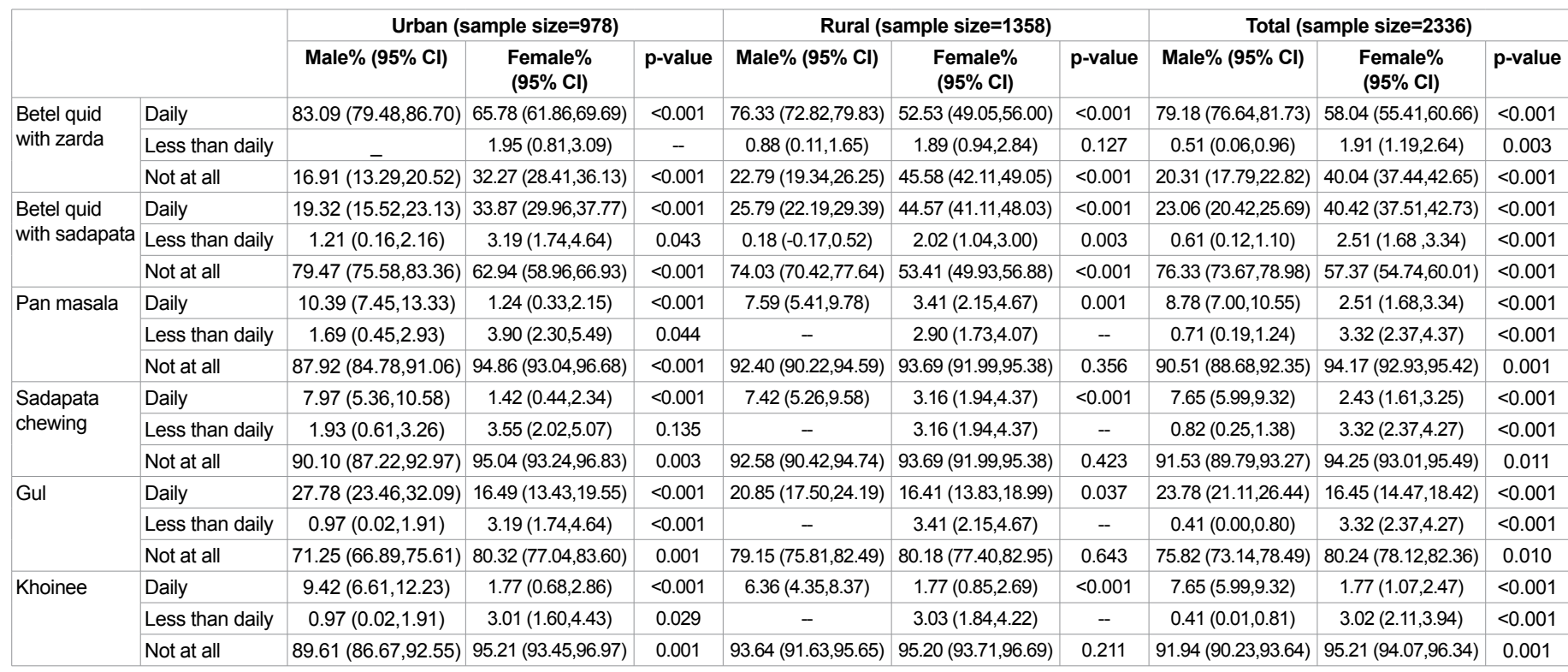

Note: $p$-values are obtained from z-test for proportion; $95 \% \mathrm{Cls}$ are obtained from $\mathrm{p} \pm 1.96 \mathrm{se}(\mathrm{p})$; - indicates N/A due to no observation; Less than daily indicates occasionally. Table 3: Current pattern of smokeless tobacco product used in Bangladesh (GATS, 2010).

\begin{tabular}{|c|c|c|c|}
\hline \multirow[t]{2}{*}{$\begin{array}{l}\text { Socio-economic and demographic } \\
\text { status }\end{array}$} & \multicolumn{2}{|c|}{$\begin{array}{c}\text { Current smokeless tobacco } \\
\text { use }\end{array}$} & \multirow[t]{2}{*}{ P-value* } \\
\hline & Yes, n (\%) & No, $n(\%)$ & \\
\hline \multicolumn{4}{|l|}{ Residence } \\
\hline Urban & $978(41.87)$ & $3,879(53.19)$ & \multirow[t]{2}{*}{$<0.001$} \\
\hline Rural & $1,358(58.13)$ & $3,414(46.81)$ & \\
\hline \multicolumn{4}{|l|}{ Gender } \\
\hline Male & $980(41.95)$ & $3,488(47.83)$ & \multirow[t]{2}{*}{$<0.001$} \\
\hline Female & $1,356(58.05)$ & $3,805(52.17)$ & \\
\hline \multicolumn{4}{|l|}{ Age $(y)$} \\
\hline$\leq 24$ & $96(4.11)$ & $1,977(27.11)$ & \multirow[t]{4}{*}{$<0.001$} \\
\hline $25-34$ & $421(18.02)$ & $2,244(30.77)$ & \\
\hline $35-44$ & $774(33.13)$ & $1,763(24.17)$ & \\
\hline$\geq 45$ & $1,045(44.73)$ & 1,309 (17.95) & \\
\hline \multicolumn{4}{|l|}{ Level of Education } \\
\hline No formal schooling & $1,318(57.08)$ & $2,098(28.91)$ & \multirow[t]{7}{*}{$<0.001$} \\
\hline Less than primary school completed & $366(15.85)$ & $1,121(15.45)$ & \\
\hline Primary school completed & $254(11.00)$ & $861(11.87)$ & \\
\hline Less than secondary school completed & $243(10.52)$ & $1,694(23.35)$ & \\
\hline Secondary school completed & $61(2.64)$ & $602(8.30)$ & \\
\hline High school completed & $29(1.26)$ & $434(5.98)$ & \\
\hline College completed or higher & $38(1.65)$ & $446(6.15)$ & \\
\hline \multicolumn{4}{|l|}{ Work status } \\
\hline Employee (Govt. Non-Govt.) & $141(6.04)$ & $820(11.24)$ & \multirow[t]{7}{*}{$<0.001$} \\
\hline Business (small/large) & $212(9.08)$ & $781(10.71)$ & \\
\hline Farming (land owner and farmer) & $239(10.23)$ & $587(8.05)$ & \\
\hline $\begin{array}{l}\text { Agri or industrial worker/daily labour/ } \\
\text { other self employed }\end{array}$ & $410(17.55)$ & $1127(15.45)$ & \\
\hline homemaker/housework & $1,067(45.68)$ & $2,963(40.63)$ & \\
\hline $\begin{array}{l}\text { Retired and unemployed (able/unable } \\
\text { to work) }\end{array}$ & $130(5.57)$ & $297(4.07)$ & \\
\hline Student/Others & $137(5.86)$ & $718(9.85)$ & \\
\hline \multicolumn{4}{|l|}{ Wealth Index } \\
\hline Poorest & $638(27.31)$ & $1,228(16.84)$ & \multirow[t]{5}{*}{$<0.001$} \\
\hline Poor & $582(24.91)$ & $1,486(20.38)$ & \\
\hline Middle & $424(18.15)$ & $1,308(17.94)$ & \\
\hline Rich & $438(18.75)$ & $1,602(21.97)$ & \\
\hline Richest & $254(10.87)$ & $1,669(22.88)$ & \\
\hline
\end{tabular}

"P-values are obtained from Chi-square test (Pearson Chi-square or Likelihood Ratio whichever applicable). 95\% Cls are obtained from $\mathrm{p} \pm 1.96 \mathrm{se}(\mathrm{p})$. - indicates N/A due to no observation. Total sample size $=9629$.

Table 4: Current smokeless tobacco consumption (daily) by socio-economic and demographic factors.

\begin{tabular}{|c|c|c|}
\hline $\begin{array}{l}\text { Socio-economic and demographic } \\
\text { status }\end{array}$ & $\begin{array}{l}\text { Prevalence }(95 \% \\
\mathrm{CI}) \text { Unadjusted }\end{array}$ & $\begin{array}{l}\text { Prevalence (95\% } \\
\mathrm{Cl}) \text { Age Adjusted }\end{array}$ \\
\hline \multicolumn{3}{|l|}{ Residence } \\
\hline Urban & $20.14(19.01,21.26)$ & $21.04(19.94,22.14)$ \\
\hline Rural & $28.46(27.18,29.74)$ & $27.42(26.23,28.60)$ \\
\hline \multicolumn{3}{|l|}{ Gender } \\
\hline Male & $21.93(20.72,23.15)$ & $21.04(19.94,22.14)$ \\
\hline Female & $26.27(25.07,27.47)$ & $27.42(26.23,28.59)$ \\
\hline \multicolumn{3}{|l|}{ Educational Level } \\
\hline College completed or higher & $7.85(5.45,10.25)$ & $8.00(5.66,10.35)$ \\
\hline High school completed & $6.26(4.06,8.07)$ & $7.79(5.18,10.40)$ \\
\hline Secondary school completed & $9.20(7.00,11.40)$ & $11.83(9.19,14.46)$ \\
\hline Less than secondary school completed & $12.55(11.07,14.02)$ & $16.01(14.27,17.76)$ \\
\hline Primary school completed & $22.78(20.32,25.24)$ & $25.89(23.33,28.44)$ \\
\hline Less than primary school completed & $24.61(22.42,26.80)$ & $25.24(23.12,27.36)$ \\
\hline No formal schooling & $38.58(36.95,40.21)$ & $32.60(31.10,34.09)$ \\
\hline \multicolumn{3}{|l|}{ Work Status } \\
\hline Employee (Govt. Non-Govt.) & $14.67(12.44,16.91)$ & $16.96(14.69,19.24)$ \\
\hline Business (small/large) & $21.35(18.80,23.90)$ & $20.90(18.63,23.17)$ \\
\hline Farming (land owner and farmer) & $28.93(25.84,32.03)$ & $22.32(19.88,24.75)$ \\
\hline $\begin{array}{l}\text { Agri or industrial worker/daily labour/ } \\
\text { other self employed }\end{array}$ & $26.68(24.46,28.89)$ & $28.07(25.99,30.15)$ \\
\hline Homemaker/housework & $26.48(25.11,27.84)$ & $27.69(26.40,28.98)$ \\
\hline $\begin{array}{l}\text { Retired and unemployed (able/unable } \\
\text { to work) }\end{array}$ & $30.44(26.08,34.81)$ & $12.03(9.72,14.33)$ \\
\hline Student/Others & $16.03(13.56,18.48)$ & $24.51(21.34,27.68)$ \\
\hline \multicolumn{3}{|l|}{ Wealth Index } \\
\hline Richest & $13.21(11.70,14.72)$ & $13.36(11.92,14.81)$ \\
\hline Rich & $21.47(19.69,23.25)$ & $21.89(20.19,23,59)$ \\
\hline Middle & $24.48(22.46,26.51)$ & $25.06(23.13,26.98)$ \\
\hline Poor & $28.14(26.20,30.08)$ & $29.12(27.28,30.97)$ \\
\hline Poorest & $34.19(32.04,36.34)$ & $31.93(29.96,33.90)$ \\
\hline
\end{tabular}

Table 5: Age adjusted and unadjusted prevalence of smokeless tobacco use (daily) in Bangladesh.

covered in other multicounty surveys and confirm that smokeless tobacco use was higher among women, the less educated, and the poor, particularly those living in rural areas. Prevalence of consuming betel quid with zarda (snuffs by mouth) was more among urban male and 


\begin{tabular}{|c|c|c|}
\hline $\begin{array}{l}\text { Socio-economic and demographic } \\
\text { factors }\end{array}$ & $\begin{array}{l}\text { Unadjusted } \\
\text { OR }(95 \% \mathrm{Cl})\end{array}$ & $\begin{array}{l}\text { Adjusted } \\
\text { OR (95\% Cl) }\end{array}$ \\
\hline \multicolumn{3}{|l|}{ Residence } \\
\hline Urban (RC) & 1.00 & 1.00 \\
\hline Rural & $1.58(1.44-1.73)$ & $1.13(1.00-1.26)$ \\
\hline \multicolumn{3}{|l|}{ Gender } \\
\hline Male (RC) & 1.00 & 1.00 \\
\hline Female & $1.27(1.15-1.39)$ & $1.70(1.41-2.05)$ \\
\hline \multicolumn{3}{|l|}{ Age group (years) } \\
\hline$\leq 24(\mathrm{RC})$ & 1.00 & 1.00 \\
\hline $25-34$ & $3.86(3.07-4.86)$ & $3.61(2.85-4.57)$ \\
\hline $35-44$ & $9.04(7.24-11.28)$ & $8.48(6.72-10.71)$ \\
\hline$\geq 45$ & $16.44(13.19-20.49)$ & $14.72(11.61-18.64)$ \\
\hline P-value for trend & $<0.001$ & $<0.001$ \\
\hline \multicolumn{3}{|l|}{ Educational Level } \\
\hline College completed or higher & 1.00 & 1.00 \\
\hline High school completed & $0.78(0.48-1.29)$ & $1.04(0.62-1.75)$ \\
\hline Secondary school completed & $1.19(0.78-1.82)$ & $1.61(1.03-2.50)$ \\
\hline $\begin{array}{l}\text { Less than secondary school } \\
\text { completed }\end{array}$ & $1.68(1.18-2.41)$ & $2.23(1.51-3.28)$ \\
\hline Primary school completed & $3.46(2.42-4.96)$ & $3.75(2.52-5.59)$ \\
\hline Less than primary school completed & $3.83(2.69-5.45)$ & $3.38(2.28-5.02)$ \\
\hline No formal schooling & $7.37(5.26-10.34)$ & $4.37(2.96-6.44)$ \\
\hline P-value for trend & $<0.001$ & $<0.001$ \\
\hline \multicolumn{3}{|l|}{ Work Status } \\
\hline Employee (Govt. Non-Govt.) & 1.00 & 1.00 \\
\hline Business (small/large) & $1.58(1.24-1.99)$ & $0.97(0.75-1.27)$ \\
\hline Farming (land owner and farmer) & $2.37(1.87-2.99)$ & $0.84(0.64-1.11)$ \\
\hline $\begin{array}{l}\text { Agri or industrial worker/daily labour/ } \\
\text { other self employed }\end{array}$ & $2.12(1.71-2.62)$ & $0.88(0.69-1.13)$ \\
\hline Homemaker/housework & $2.09(1.73-2.54)$ & $0.72(0.56-0.94)$ \\
\hline $\begin{array}{l}\text { Retired and unemployed (able/unable } \\
\text { to work) }\end{array}$ & $2.55(1.94-3.34)$ & $0.83(0.60-1.14)$ \\
\hline Student/Others & $1.11(0.86-1.43)$ & $1.12(0.83-1.51)$ \\
\hline $\mathrm{P}$-value for trend & 0.001 & $<0.001$ \\
\hline \multicolumn{3}{|l|}{ Wealth Index } \\
\hline Richest (RC) & 1.00 & 1.00 \\
\hline Rich & $1.79(1.52-2.13)$ & $1.32(1.09-1.61)$ \\
\hline Middle & $2.13(1.79-2.53)$ & $1.39(1.12-1.70)$ \\
\hline Poor & $2.57(2.19-3.03)$ & $1.64(1.33-2.02)$ \\
\hline Poorest & $3.41(2.90-4.02)$ & $1.79(1.44-2.21)$ \\
\hline P-value for trend & $<0.001$ & $<0.001$ \\
\hline
\end{tabular}

$p$-Value from Hosmer Lemeshow goodness of fit test $=0.223, \mathrm{AUC}=0.773$. for trend are for more than three categories; AUC, Area Under ROC Curves is for prediction accuracy of the adjusted model; Hosmer Lemeshow test and AUC is for goodness of fit of the adjusted model.

Table 6: Adjusted and unadjusted odds ratios derived from logistic regression to current smokeless tobacco use (daily) in Bangladesh.

among urban female and all other products (pan masala, sadapata chewing, Gul, Khoinee) are less consumed comparatively. Analytical result also provides that older people use smokeless tobacco most and job has not been found to play any significant role for smokeless tobacco use among the respondents. It might be due to the fact of social norm of Bangladesh. Smokeless tobacco product consumption is socially well accepted in Bangladesh and it is a tradition of culture that older people gossips together to pass their time and offers tobacco with zarda to chew. The same scenario was found in previous studies [14].

The major strengths of our study include large sample size, the coverage of men and women smokeless tobacco user, the coverage of both rural and urban areas, and the nationally representative population. However, there are several limitations that need to be addressed. The findings in this report are based on self-reports. Furthermore, education categories were combined into broad groupings, which could have contributed to biased estimates in terms of the gradients observed [7]. Nonetheless, these groupings provided greater precision than those used in earlier tobacco use research in Bangladesh. The data used in constructing wealth index is based on limited number of asset variables, which might result in incomplete or under representing socioeconomic status. Some other variables like psychological variables could provide more predicting accuracy, but no such variable was available.

To reduce the epidemic of diseases caused by smokeless tobacco use, we need to take action to reduce the use of these products. Policymakers need to consider smokeless tobacco use separately in tobacco control efforts, since the economic and health effects of smokeless tobacco use are different from that of smoking $[15,16]$. Given the wide acceptance of smokeless tobacco use in Bangladeshi culture, interventions to raise awareness of the harms of smokeless tobacco use should target women, especially older as a key group. At the same time, national campaign programs should focus on changing social norms by addressing inappropriate attitudes and perceptions of risk towards smokeless tobacco use among the Bangladeshis. Similar to the effective policies for tobacco smoking, policies such as increasing excise tax and restricting marketing of smokeless tobacco to targeted population including minors, should also be initiated. These interventions should complement the existing intervention strategies aimed at reducing smokeless tobacco use among the public in Bangladesh.

\section{Acknowledgments}

We acknowledge the members of the GATS Collaborative Group.

\section{References}

1. Khan NR, Mahmood AR (2015) Pattern of tobacco consumption and related factors among the people residing in a rural area. Bangladesh Med J 44.

2. Choudhury K, Hanifi SMA, Mahmood SS, Bhuiya A (2007) Sociodemographic Characteristics of Tobacco Consumers in a Rural Area of Bangladesh. Journal of Health, Population and Nutrition 25: 456-464.

3. Erens B, Primatesta P, Prior G (2001) Health Survey for England 1999. London: The Stationary Office.

4. Zaman MM, Nargis N, Perucic AM, Rahman K (2007) Impact of Tobacco Related IIIness in Bangladesh. World Health Organization, Regional Office for South East Asia, New Delhi.

5. Giovino GA, Mirza SA, Samet JM, Gupta PC, Jarvis MJ, et al. (2012) Tobacco use in 3 billion individuals from 16 countries: an analysis of nationally representative cross-sectional household surveys. Lancet 380: 668-679.

6. Kalsbeek WD, Bowling JM, Hsia J (2012) The Global Adult Tobacco Survey (GATS): sample design and related methods.

7. Sultana P, Akter S, Rahman MM, Alam MS (2015) Prevalence and Predictors of Current Tobacco Smoking in Bangladesh. J Biometrics and Its Aplication 1: 1-8.

8. Global Adult Collaborative Group. Global Adult Tobacco Survey (GATS) quality assurance, guidelines and documentation, version 2.0 .

9. Mishra GA, Kulkarni SV, Gupta SD, Shastri SS (2015) Smokeless tobacco use in Urban Indian women: Prevalence and predictors. Indian Journal of Medical and Pediatric Oncology 36: 176-182.

10. Rooban T, Elizabeth J, Umadevi KR, Ranganathan K (2010) Sociodemographic correlates of male chewable smokeless tobacco users in India: a preliminary report of analysis of National Family Health Survey, 2005-2006. Indian J Cancer 1: 91-100.

11. Abdullah AS, Driezen P, Ruthbah UH, Nargis N, Quah ACK, et al. (2014) Patterns and Predictors of Smokeless Tobacco Use among Adults in Bangladesh: Findings from the International Tobacco Control (ITC) Bangladesh Survey. PLoS ONE 9: e101934. 
Citation: Begum M, Sultana P (2017) Current Pattern of Product Specific Smokeless Tobacco Use in Bangladesh. J Biom Biostat 8: 362. doi: 10.4172/2155-6180.1000362

Page 6 of 6

12. Bedi R, Gilthorpe MS (1995) The prevalence of betel-quid and tobacco chewing among the Bangladesh community residents in a United Kingdom area of multiple deprivation. Primary dental care: Journal of the Faculty of General Dental Practitioners (UK) 2: 39-42.

13. Sinha DN, Gupta PC, Ray C, Singh PK (2012) Prevalence of smokeless tobacco use among adults in WHO South-East Asia. Indian J Cancer 49: 342-346.

14. Hossain MS, Kypri K, Rahman B, Arslan, Akter S, et al. (2014) Prevalence and Correlates of Smokeless Tobacco Consumption among Married Women in Rural Bangladesh. PLoS ONE 9: e84470.

15. Sinha DN, Rizwan SA, Aryal KK, Karki KB, Zaman MM, et al. (2015) Trends of Smokeless Tobacco Use among Adults (Aged 15-49 Years) in Bangladesh. India and Nepal Asian Pacific Journal of Cancer Prevention 16: 6561-6568.

16. West R, McNeill A, Raw M (2004) Smokeless tobacco cessation guidelines for health professionals in England. British Dental Journal 196: 611-618. 